\title{
Penerapan Asuhan Kefarmasian dan Media Sosial dalam Meningkatkan Pendapatan Apotek
}

\author{
Alwiyah Mukaddas ${ }^{1}$, M. Sulaiman Zubair ${ }^{2}$, Yusriadi $^{2}$ \\ 1,2 Universitas Tadulako, Indonesia
}

\begin{tabular}{|c|c|}
\hline \multicolumn{2}{|r|}{ A B S T R A C T } \\
\hline $\begin{array}{l}\text { IMPLEMEN } \\
\text { MARKETIN } \\
\text { pharmaceut } \\
\text { functions, } w \\
\text { activity is } t \\
\text { marketing } t \\
\text { the adding } \\
\text { medical dev } \\
\text { form of CIE } \\
\text { other healtl } \\
\text { includes Fac } \\
\text { an impact o } \\
\text { application } \\
\text { of internet-b }\end{array}$ & $\begin{array}{l}\text { TATION OF PHARMACEUTICAL CARE AND SOCIAL MEDIA } \\
\text { G IN IMPROVING THE PHARMACY OMZET. A pharmacy is a place for } \\
\text { cal practice of pharmacists. Apotek Pendidikan Tadulako has three } \\
\text { ich are education, social and business/profit functions. The purpose of this } \\
\text { improve the pharmaceutical care, inventory management aspects, and } \\
\text { at affect to the increasing of pharmacy omzet. The solutions offered include } \\
\text { f a variety of non-drug supplies in the form of vaccines and home care } \\
\text { ces, strengthening of pharmacists role in providing plenary services in the } \\
\text { (Consultation, Information, Education), establishing the cooperation with } \\
\text { institutions, and implementing the social media marketing (SMM) } \\
\text { book, Instagram, Twitter and YouTube. The results of these activities have } \\
\text { increasing the omzet of pharmacy every month. The follow-up plan is the } \\
\text { f an integrated Management Information System (SIM) and the application } \\
\text { ised marketing techniques with a website that is an online pharmacy. }\end{array}$ \\
\hline Keywords: & $\begin{array}{l}\text { Apotek Pendidikan Tadulako, Home Care, Medical Devices, Social Media } \\
\text { Marketing. }\end{array}$ \\
\hline $\begin{array}{l}\text { Received: } \\
18.09 .2019\end{array}$ & $\begin{array}{ll}\text { Accepted: } & \text { Available online: } \\
03.02 .2020 & 20.02 .2020\end{array}$ \\
\hline
\end{tabular}

\section{Suggested citation:}

Mukaddas, A., Zubair, M., \& Yusriadi. (2020). Penerapanan asuhan kefarmasian dan media sosial dalam meningkatkan pendapatan apotek. Jurnal Pengabdian Pada Masyarakat, 5(1), 26-34. https://doi.org/10.30653/002.202051.243

Open Access I URL: http://ppm.ejournal.id/index.php/pengabdian/article/view/243

\footnotetext{
${ }^{1}$ Corresponding Author: Jurusan Farmasi, FMIPA, Universitas Tadulako, Palu; Jl. Soekarno-Hatta KM. 9,5, Tondo, Mantikulore, Palu; Email: alwiyah.mukaddas@gmail.com
} 


\section{PENDAHULUAN}

Apotek menurut Peraturan Menteri Kesehatan Nomor 9 tahun 2017 adalah sarana pelayanan kefarmasian tempat dilakukan praktik kefarmasian oleh Apoteker (Permenkes 9-2017 Apotek.pdf, t.t.). Apoteker Farmasi komunitas adalah tenaga kesehatan yang paling mudah di akses oleh masyarakat luas. Oleh karena itu, optimalisasi praktik kefarmasian oleh apoteker untuk menerapkan asuhan kefarmasian (pharmaceutical care) di apotek sebagai ujung tombak layanan kesehatan harus terus ditingkatkan. Namun, hasil penelitian menunjukkan bahwa kinerja apoteker dalam memberikan informasi obat masih kurang dibandingkan dokter dengan nilai gap minus $(-0,27)$ (Hutami \& Rokhman, 2013). Apotek Pendidikan Tadulako (PenTa) merupakan apotek pioner yang melaksanakan implementasi PP Nomor 51 tahun 2009 dan Permenkes Nomor 35 tahun 2014 secara komprehensif dan berkesinambungan. Apotek PenTa adalah unit usaha yang dalam pelaksanaannya mempunyai tiga fungsi yaitu fungsi pendidikan, fungsi sosial dan fungsi bisnis/profit (Mukaddas, Zubair, \& Yusriadi, 2019).

Apotek PenTa telah berdiri sejak keluarnya izin pertama kali oleh Apoteker Pengelola Apotek (APA) Nurhalifah Ibrahim, S.Farm., Apt. (alm.) dengan SIA (Surat Izin Apotek) Nomor : 27/16.30/DPMPTSP/IV/2018, tanggal 23 April 2018. Mulai beroperasi sejak 1 Juli 2018 karena proses perbaikan yang membutuhkan waktu lama dan membuat jalinan kerjasama dengan Fakultas Kedokteran Universitas Tadulako yang akan mendirikan Klinik Pratama sebagai persiapan kerjasama dengan BPJS Kesehatan layanan kesehatan tingkat 1 . Namun, sebelum kerjasama dengan BPJS kesehatan terjalin dan masa operasi apotek dan klinik selama 3 bulan terjadi bencana alam gempa bumi, tsunami dan liquifaksi. yang melanda Kota Palu dan sekitarnya sehingga apotek tidak beroperasi selama kurang lebih 1 bulan dan selama masa pemulihan kejadian persediaan obat-obatan tidak terdata dan diberikan gratis kepada masyarakat sekitar yang membutuhkan saat itu karena halaman apotek menjadi salah satu tempat pengungsian sementara dan terjadi kerusakan beberapa perlengkapan SIM (Sistem Informasi Manajemen).

Bencana alam memberikan pengaruh yang signifikan terhadap penurunan omzet apotek PenTa. Oleh karena itu, diperlukan teknik pemasaran yang maksimal tanpa biaya promosi yang dapat semakin menggerus pendapatan apotek. Social media marketing (SMM) adalah salah satu teknik pemasaran berbasis internet yang memiliki dua benefit yaitu biaya yang rendah dan kemungkinan besar meningkatkan pendapatan ( $\mathrm{Si}$, 2016). Media social yang banyak digunakan oleh berbagai lapisan masyarakat ada 4 yaitu facebook, instagram, twitter, dan youtube. Hasil penelitian menunjukkan bahwa ada hubungan antara aktivitas social media marketing facebook dengan brand awareness service mobile provider di Mesir (ElAydi, 2018). Peran social media pada pengembangan e-commerce menunjukkan bahwa interaksi konsumen melalui media social akan meningkatkan kepercayaan dan keinginan untuk membeli produk yang ditawarkan (Hajli, 2014).

Penerapan asuhan kefarmasian yang lebih baik dan penggunaan social media marketing diharapkan berpengaruh positif pada perkembangan apotek dan mampu meningkatkan pendapatan apotek. 


\section{METODE}

Metode pendekatan yang digunakan dalam kegiatan ini meliputi:

1) Penambahan variasi jenis persediaan obat dan non-obat

Variasi jenis persediaan berupa obat, vaksin, dan alat kesehatan home care melalui distributor pedagang besar farmasi (PBF) resmi yang ada di Kota Palu. Jumlah PBF di Kota Palu berkurang sehingga ketersediaan perbekalan farmasi saat ini terbatas. Penyediaan alat kesehatan home care dan perbekalan farmasi lainnya diperoleh dari distributor alat kesehatan yang berizin di kota lain seperti Jakarta.

Untuk mengetahui jenis obat dan alat kesehatan home care yang banyak digunakan oleh masyarakat maka diedarkan kuesioner melalui google form dengan target mahasiswa Jurusan farmasi FMIPA, Untad.

2) Penguatan peran apoteker dalam menerapkan asuhan kefarmasian

Layanan paripurna berupa KIE (Konsultasi, Informasi, dan Edukasi) berbagai jenis persediaan apotek yaitu perbekalan farmasi obat dan alat kesehatan. Layanan dapat terlaksana dengan menerapkan "no pharmacist no service"I dimana pengelolaan apotek hanya dilakukan oleh apoteker yang standbay Idi apotek dan melakukan proses komunikasi yang bisa meningkatkan kepuasan pasien.

3) Menjalin kerjasama dengan institusi kesehatan lain

Meningkatkan kerjasama dengan Institusi kesehatan lain seperti Rumah Sakit Umum (RSU) Tadulako berupa layanan vaksinasi dan kerjasama kegiatan social dengan organisasi IAI (Ikatan Apoteker Indonesia) dan ormas lainnya sebagai sarana promosi. 4) Penerapan social media marketing (SMM)

Penggunaan social media marketing meliputi facebook, Instagram, twitter, dan kanal youtube sebagai salah satu teknik pemasaran berbasis internet untuk meningkatkan pendapatan apotek.

\section{HASIL DAN PEMBAHASAN}

Apotek PenTa sebagai unit usaha berbadan hukum mengurus kembali perizinan karena APA sebelumnya meninggal dunia sebagai korban bencana alam 28 September 2018. APA berikutnya dipegang oleh Ketua Jurusan Farmasi Fakultas Matematika dan Ilmu Pengetahuan Alam Universitas Tadulako (FMIPA-UNTAD) yaitu M. Sulaiman Zubair, M.Si., PhD, Apt. sekaligus anggota tim pengabdi PPUPIK Apotek Pendidikan Tadulako. Selain itu, diangkat 2 Apoteker Pendamping (Aping) lulusan S1 Jurusan Farmasi Fakultas Matematika dan Ilmu Pengetahuan Alam Universitas Tadulako (FMIPA-UNTAD) untuk membantu pengelolaan apotek dikarenakan APA tidak bisa melakukan pelayanan kefarmasian di apotek setiap saat. Proses perizinan berjalan cukup lama di mulai bulan Februari 2019 sampai bulan April karena kantor perizinan dan Dinas kesehatan Kota Palu juga mengalami kerusakan. Surat izin kedua Apotek PenTa Nomor :06/R/16.30/DPMPTSP/IV/2019 tanggal 08 April 2019, sehingga proses pelayanan kefarmasian berupa pembelian obat-obatan melalui PBF dan penjualan sudah berjalan seperti sebelumnya.

Apotek pendidikan tadulako di miliki sepenuhnya oleh universitas tadulako dan pengelolaannya saat ini melalui Jurusan Farmasi FMIPA-UNTAD sebagai Pelaksana 
Pengelolaan Apotek Pendidikan Tadulako sesuai SK Rektor Nomor 4226/UN28/KL/2019 pada tanggal 15 Mei 2019 dan pengangkatan tim pengelola apotek pendidikan tadulako tahun 2019 menurut keputusan Rektor Untad Nomor 4244/UN28/KP/2019 pada tanggal 16 Mei 2019.

Pengadaan perbekalan kefarmasian mengalami hambatan karena kurangnya pendanaan sehingga system konsinyasi cukup membantu dalam peningkatan jumlah persediaan apotek. Hal ini berpengaruh pada omzet/pendapatan apotek yang sangat rendah dari penjualan perbekalan kefarmasian terutama obat-obatan. Selain itu, jalinan kerjasama RSU tadulako dan BPJS Kesehatan yang tidak berlanjut menyebabkan penurunan angka kunjungan pasien di RS berpengaruh signifikan pada omzet apotek PenTa yang berada dalam satu gedung dengan RSU Tadulako. Langkah-langkah yang dilakukan untuk meningkatkan omzet apotek PenTa adalah sebagai berikut:

Penambahan variasi jenis persediaan obat dan non-obat berupa vaksin dan alat kesehatan home care.

Perbekalan kefarmasian berupa obat, vaksin, dan alat kesehatan (alkes) home care tersedia di pasaran dengan berbagai macam jenis dan kegunaan yang bisa saja serupa. Oleh karena itu, dilakukan pembagian kuesioner menggunakan google form dan diedarkan di kalangan mahasiswa farmasi untad. Hasil kuesioner adalah sebagai berikut:

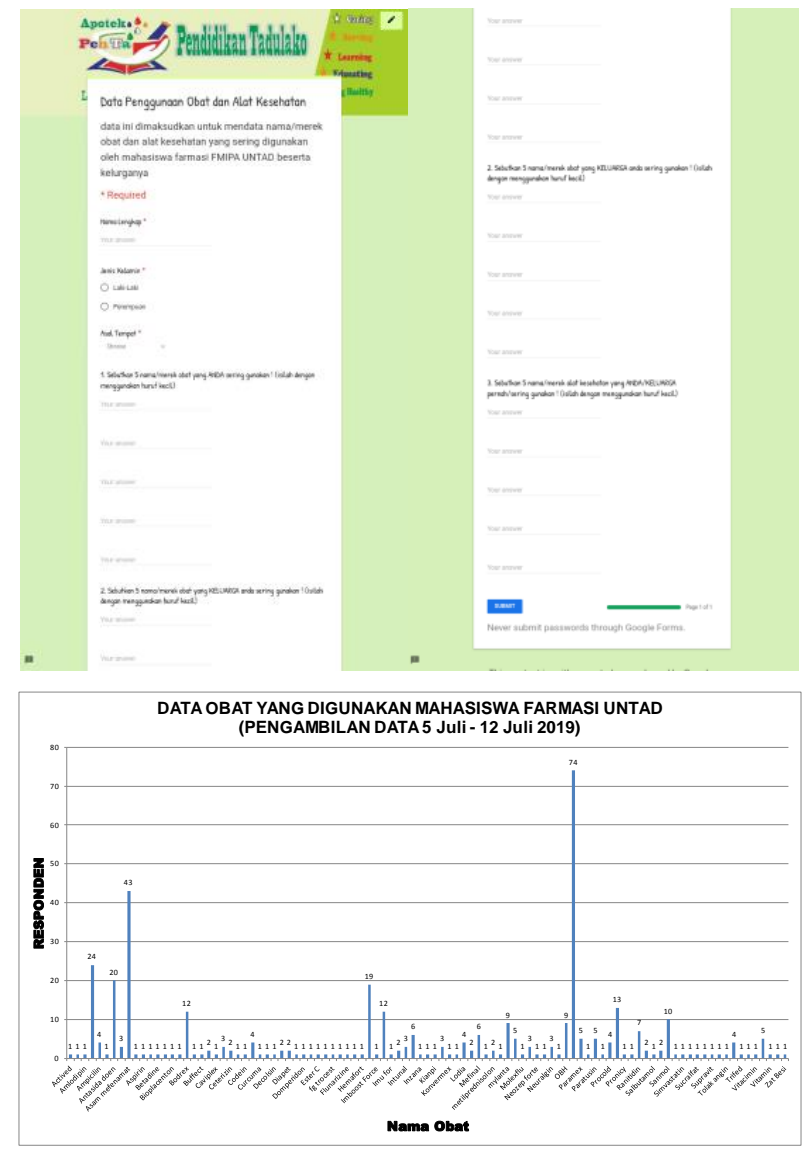

Gambar 2. Data Obat yang digunakan 


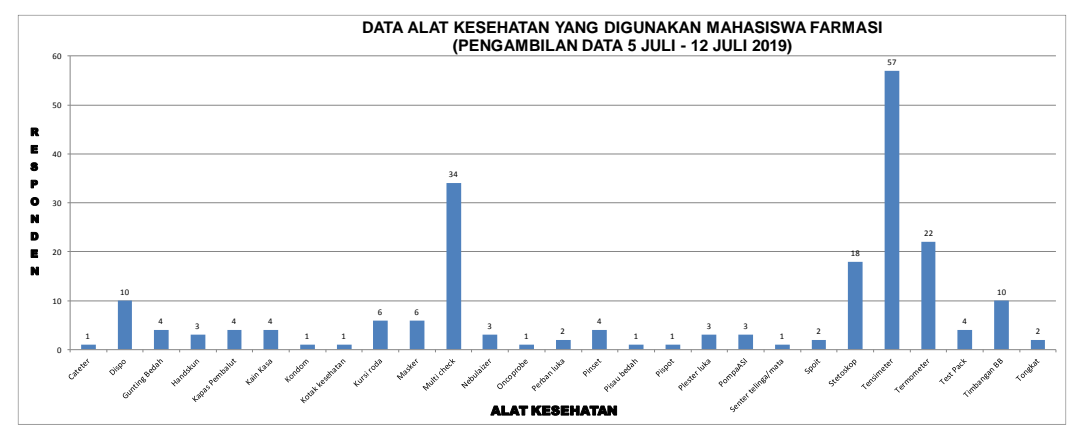

Gambar 3. Data alat kesehatan yang digunakan

Hasil kuesioner menunjukkan bahwa jenis obat yang paling banyak digunakan adalah paracetamol, asam mefenamat, dan antasida. Alat kesehatan yang paling dominan adalah tensimeter, alat multicheck, dan thermometer. Saat ini apotek PenTa telah menyediakan berbagai macam alat kesehatan dari berbagai merek seperti berbagai jenis thermometer Infra-red (IR), thermometer digital, thermometer non-contact/forehead, alat pengukur tekanan darah digital/tensimeter berbagai jenis, bantal panas dingin (hot/cold pack), pispot pria dan wanita, alat pengukur multicheck kadar gula, kolesterol dan asam urat berbagai merk, alat-alat fisiotherapy seperti berbagai jenis tongkat dan kursi roda, bola duri dengan magnetic, dan lain-lain. Penjualan alkes cukup membantu penjualan apotek saat ini. Selain itu, beberapa mahasiswa penelitian dari Jurusan Farmasi Untad juga sangat terbantu dengan adanya penyediaan alkes seperti diatas karena apotek dapat membantu memilihkan alat yang baik dan tepat untuk digunakan sebagai alat ukur penelitian dengan harga yang terjangkau oleh mahasiswa. Perbekalan farmasi yang dibutuhkan oleh Jurusan Farmasi kedepannya akan disediakan oleh apotek pendidikan tadulako.

\section{Penguatan peran apoteker dalam menerapkan asuhan kefarmasian}

Apoteker dalam lingkup komunitas berfungsi sebagai nara sumber utama informasi perbekalan kefarmasian terutama obat-obatan dan alat kesehatan home care. Saat ini alkes tersebut sering direkomendasikan oleh para klinisi dalam memonitoring terapi berbagai penyakit kronis untuk memastikan ketercapaian tujuan terapi. Kelemahan toko atau distributor alkes adalah tidak adanya informasi tentang cara penggunaan yang baik dan benar, pemeliharaan, penyimpanan alat, serta informasi interpretasi data hasil pemeriksaan menggunakan alat tersebut. Apoteker berfungsi memberikan layanan simulasi penggunaan alat tersebut dengan paripurna sehingga alkes home care dapat dimanfaatkan dengan maksimal oleh pasien. Hal ini sesuai dengan penerapan Permenkes RI Nomor 9 Tahun 2017 tentang apotek bahwa apoteker dapat menyediakan dan menyerahkan sediaan farmasi dan/atau alat kesehatan bagi pasien. KIE (Komunikasi, Informasi dan Edukasi) pasien oleh apoteker adalah salah satu implementasi pharmaceutical care yang bisa meningkatkan kepuasan pasien yang berpengaruh pada pendapatan apotek. Hasil penelitian menunjukkan bahwa 340 responden menginginkan keberadaan apoteker di apotek di kuadran B diagram kartesius dan memiliki nilai CSI (Costumer Satisfaction Index) kategori puas (Makadjadi, Irene, Mukaddas, Alwiyah, \& Tandah, 2016). 


\section{Menjalin kerjasama dengan institusi kesehatan lain}

Penjualan obat di apotek penta saat ini, setiap bulannya sudah mengalami peningkatan secara bertahap namun masih belum signifikan. Hal ini sangat dipengaruhi oleh keberadaan Rumah sakit umum (RSU) tadulako yang berpindah tempat ke klinik sehingga klinik pratama ditutup sampai batas waktu yang belum ditentukan. RSU tadulako saat ini juga sudah melepas kerjasama dengan BPJS kesehatan karena tidak memenuhi syarat akreditasi RS setelah berpindah tempat dari tempat sebelumnya. Hal tersebut mengakibatkan jumlah pasien menurun secara signifikan dari yang sebelumnya yang akhirnya menyebabkan apotek juga tidak mendapatkan pemasukan dari pasien RS.

Semenjak RSU Tadulako berada satu atap dengan apotek pendidikan tadulako, maka diadakan kegiatan terprogram setiap bulan dimulai bulan Juli sampai Desember 2019 berupa Bakti sosial untuk memperkenalkan RSU dan Apotek Penta serta layananlayanan kesehatan yang tersedia dikedua tempat tersebut. Kegiatan tersebut menjadi ajang promosi bagi masyarakat sekitar kelurahan Tondo khususnya dan Kota Palu pada umumnya. Sampai saat ini bakti sosial telah berlangsung tiga kali yaitu bulan Juli, Agustus, dan September 2019. Foto-foto kegiatan tersebut sebagai berikut:

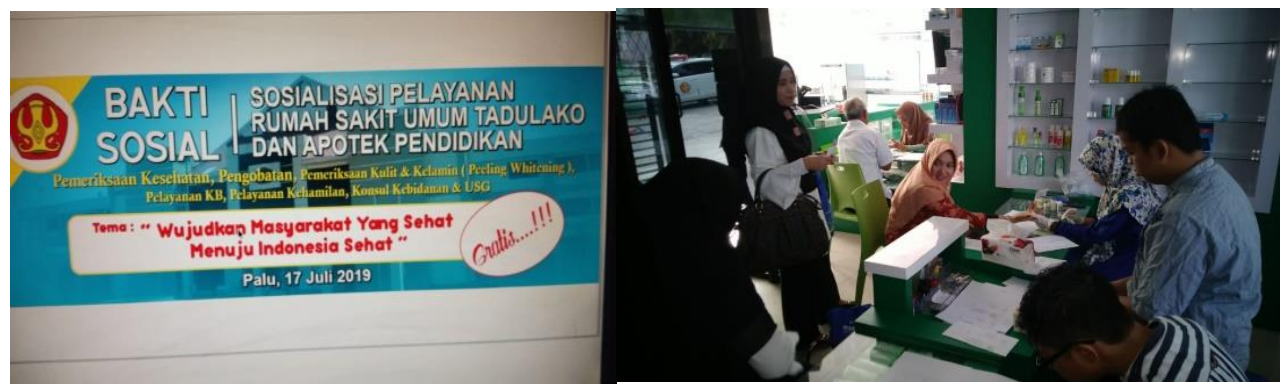

Gambar 3. Bakti sosial kerjasama RSU dan apotek pendidikan tadulako tahap pertama

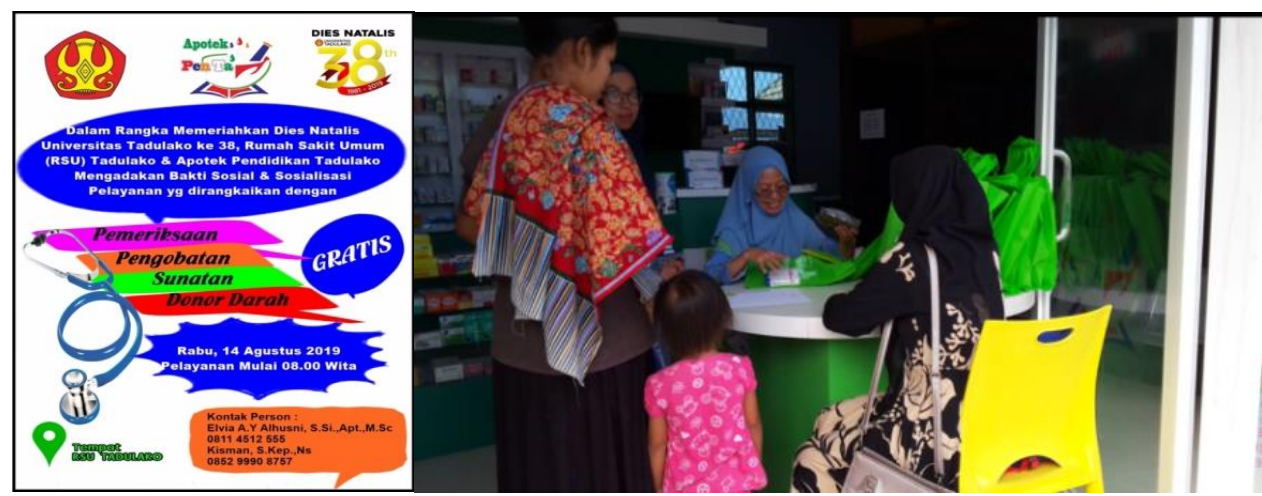

Gambar 4. Bakti sosial dalam rangka peringatan hari kemerdekaan 17 Agustus, Dies natalis Untad, RSU Tadulako \& Apotek Pendidikan Tadulako 


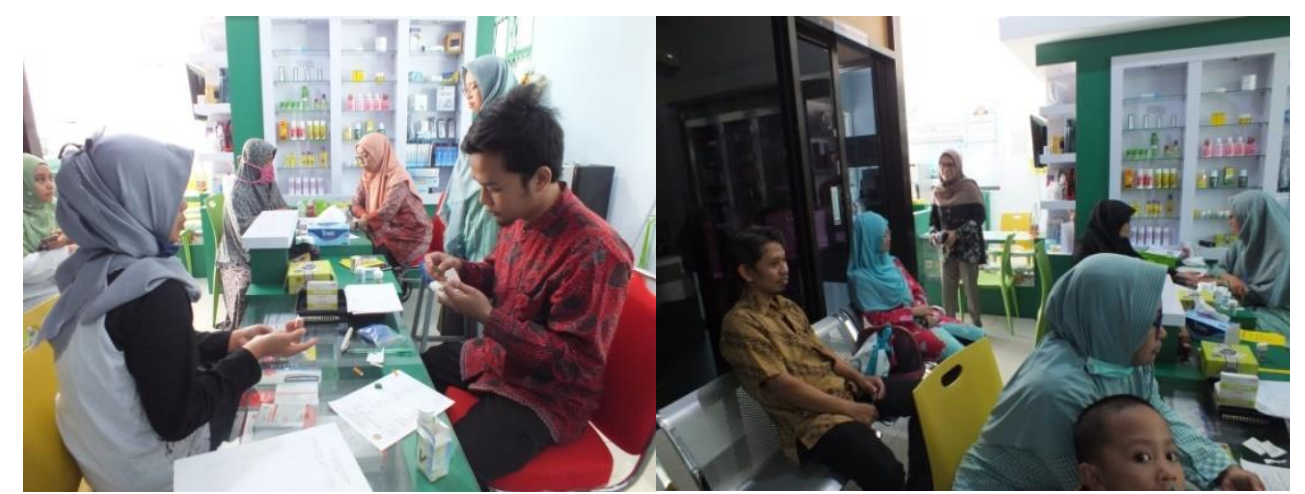

Gambar 5. Bakti sosial kerjasama RSU dan Apotek Pendidikan Tadulako tahap ketiga $(\mathrm{J}, \mathrm{K}, \mathrm{L}, \mathrm{M})$

Penerapan social media marketing (SMM) meliputi facebook, Instagram, twitter, dan kanal youtube.

Penggunaan social media marketing dapat mendorong peningkatan omzet apotek PenTa. Facebook, instagram, twitter, dan kanal youtube adalah empat media social yang paling banyak digunakan masyarakat sehingga keterjangkaun pemasaran dapat meluas dengan cepat. Penerapan SMM memberikan pengaruh positif dan terjadi peningkatan pendapatan yang cukup signifikan pada apotek PenTa sehingga perlu dilakukan dengan intensif dan berkesinambungan. Berikut ini adalah media social yang digunakan apotek PenTa sebagai alat promosi dan pemasaran produk persediaan apotek:

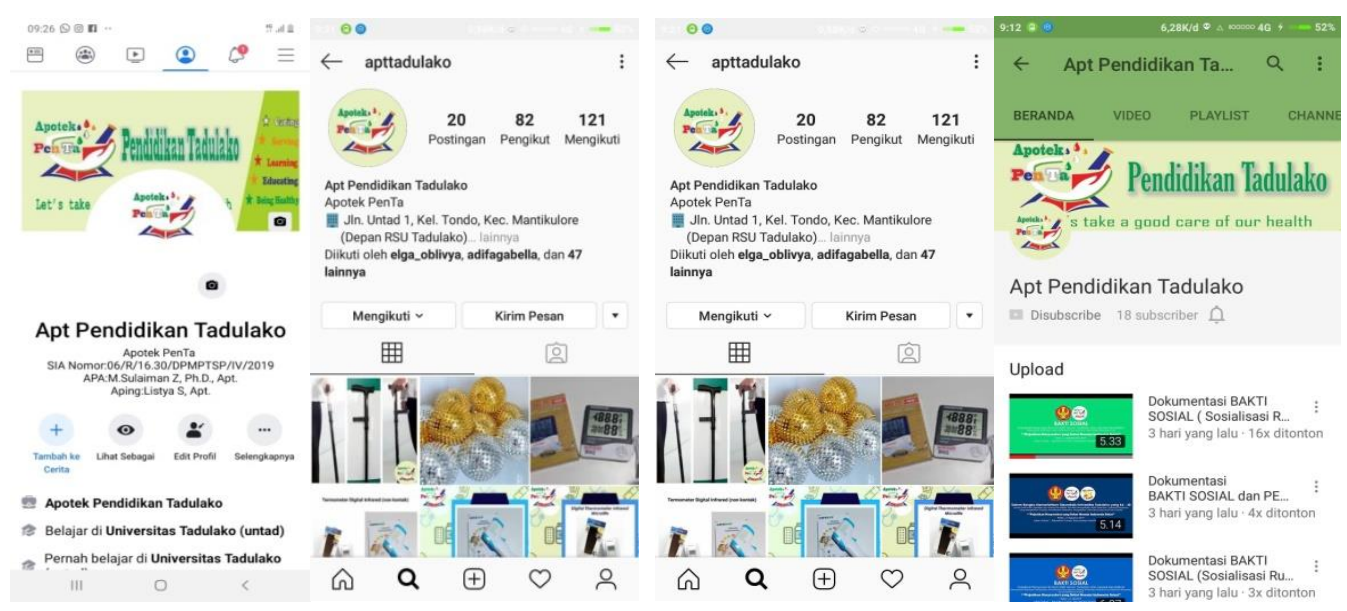

\section{Gambar 7. Twitter @apotektadulako dan Kanal Youtube Apt Pendidikan Tadulako}

Rencana tindak lanjut tahapan kegiatan pengabdian adalah sebagai berikut: Apotek PenTa akan membuat SIM (system Informasi Manajemen) dan website untuk penjualan berbasis online. Penjualan online menjadi penting sebagai persiapan menuju era industri digitalisasi 4.0 yang marak saat ini. Namun, penjualan berbasis online pada jenis perdagangan obat-obatan sampai saat ini terkendala regulasi yang belum mengatur penjualan online. Peraturan Permenkes RI Nomor 26 Tahun 2018 tentang 
pelayanan perizinan berusaha terintegrasi secara elektronik sector kesehatan (Permenkes 26, t.t.) dan Permenkes RI Nomor 9 Tahun 2017 tentang apotek.

Persiapan website yang ingin mengakomodir keinginan masyarakat farmasi khususnya dan masyarakat umum di dahului dengan diadakannya FGD (Focus group discussion) $e$-commerce : Apotek Pendidikan Tadulako (PenTa) sebagai tantangan Era Revolusi Industri 4.0, dengan mengundang berbagai stake holder di bidang kefarmasian seperti apoteker di RS, Apoteker Komunitas, Badan POM, Dinas kesehatan Kota Palu, Dinas kesehatan Provinsi Sulawesi Tengah, PBF, alumni S1 Farmasi Untad yang sudah menyelesaikan apoteker dan bekerja di berbagai bidang, dan organisasi profesi IAI yang diwakili oleh Ketua PD IAI Sulawesi Tengah dan beberapa anggota IAI lainnya. Hasil dari FGD tersebut diatas menjadi bahan pertimbangan SIM dan website yang sudah memiliki rancangan awal sebelumnya. Foto-foto kegiatan FGD di bawah ini:

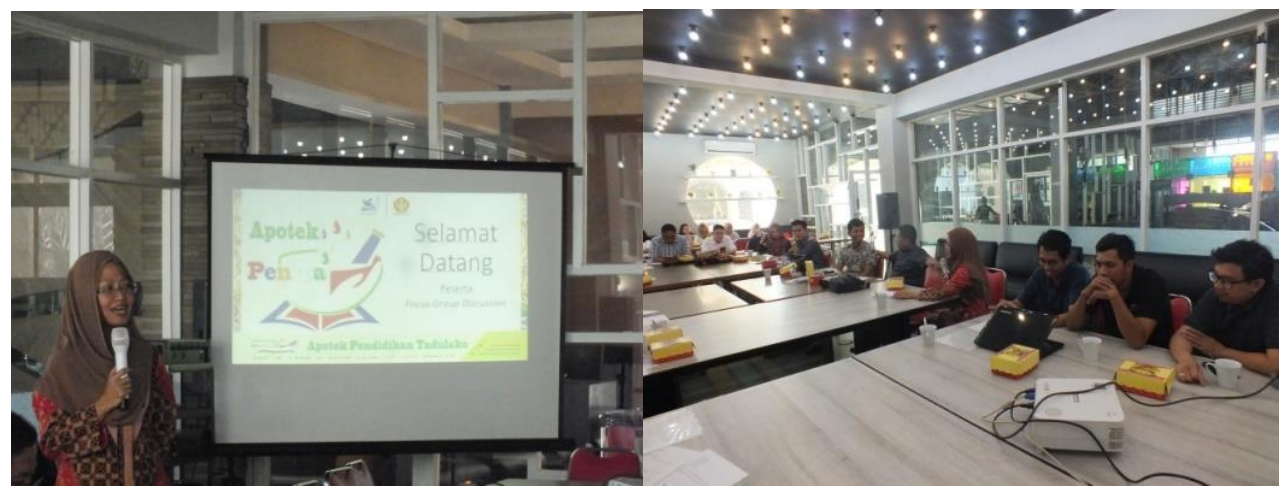

Gambar 8. FGD e-commerce

Website penjualan/apotek online nantinya akan menjadi penjualan berbasis website, namun belum berbasis aplikasi android sehingga beberapa rencana mitra apotek belum bisa terlaksana. Apotek online berbasis aplikasi android akan menjadi rencana pengembangan di tahun ketiga. Saat ini Apotek Pendidikan Tadulako harus memperbaiki system IT berupa SIM (Sistem Informasi Manajemen) yang berbasis LAN dan sistem penjualan berbasis website yang lebih lengkap.

\section{SIMPULAN}

Apotek Pendidikan Tadulako meningkatkan penerapan asuhan kefarmasian dan teknik pemasaran social media marketing (SMM) berupa facebook, instagram, twitter, dan youtube yang memberikan pengaruh positif dan peningkatan pendapatan/omzet apotek.

\section{REFERENSI}

ElAydi, H. O. (2018). The effect of social media marketing on brand awareness through facebook: an individual-based perspective of mobile services sector in Egypt. OALib, 05(10), 1-5. https://doi.org/10.4236/oalib.1104977 
Hajli, M. N. (2014). A study of the impact of social media on consumers. International Journal of Market Research, 56(3), 387-404. https://doi.org/10.2501/IJMR-2014-025

Hutami, S. T., \& Rokhman, M. R. (2013). Persepsi dan harapan konsumen apotek terhadap apoteker farmasi komunitas. Indonesian Journal of Clinical Pharmacy, 2(3), 85-93.

Makadjadi., Irene, O., Mukaddas., Alwiyah., \& Tandah, M. R.. (2016). Analysis of the patient satisfaction level to pharmacist service quality in four pharmacies in Palu city using servqual method. Proceedings International Conference and Workshop on Pharmacy and Statistics, 99-108. Kota Palu.

Mukaddas, A., Zubair, M. S., \& Yusriadi, Y. (2019). Apotek pendidikan tadulako: implementasi pharmaceutical care secara professional pada lingkup farmasi komunitas. Jurnal Pengabdian Kepada Masyarakat, 24(4), 865-869. https://doi.org/10.24114/jpkm.v24i4.11984

Menteri Kesehatan Republik Indonesia. (2018). Peraturan tentang pelayanan perizinan berusaha terintegrasi secara elektronik sektor kesehatan, Jakarta 2018.

Menteri Kesehatan Republik Indonesia. (2017). Peraturan tentang apotek, Jakarta 2017.

$\mathrm{Si}, \mathrm{S}$. (2016). Social media and its role in marketing. Business and Economics Journal, 07(1), 1-5. https://doi.org/10.4172/2151-6219.1000203

\section{Copyright and License}

This is an open access article distributed under the terms of the Creative Commons Attribution 4.0 International License, which permits unrestricted use, distribution, and reproduction in any medium, provided the original work is properly cited. (C) 2020 Alwiyah Mukaddas, M. Sulaiman Zubair, Yusriadi. 